\title{
AFIKSASI DALAM KOLOM POLITIK DI KORAN JAWA POS EDISI JUMAT 1 NOVEMBER 2019
}

\author{
Firna Putri Ananda \\ Program Studi Pendidikan Bahasa dan Sastra Indonesia, Fakultas Ilmu Pendidikan \\ Universitas Hasyim Asy'ari, firnaputriananda19@gmail.com
}

\begin{abstract}
Abstrak
Perubahan kata terdapat di berbagai sumber salah satunya di koran jawa pos, ternyata banyak kata yang mengalami perubahan kata seperti pada kolom Politik di koran Jawa Pos edisi Jumat 1 November 2019, terdapat banyak kata yang mengalami perubahan kata didalamnya. Kata-kata yang mengalami perubahan kata tersebut mengalami proses afiksasi yang merupakan bagian dari proses morfemis dalam morfologi. Penelitian ini menganalisis proses afiksasi yang terdapat pada kolom Politik di koran Jawa Pos edisi Jumat 1 November 2019. Didapatkan tiga proses perubahan kata yaitu prefiks, sufiks, dan konfiks, dari tujuh proses afiksasi. Ditemukan 20 prefiks, 7 sufiks, dan 20 konfiks. Afiksasi merupakan bentuk dasar yang mengalami proses pingimbuhan afiks dan menghasilkan kata baru. Proses afiksasi dibagi menjadi tujuh jenis yaitu prefiks, sufiks, infiks, konfiks, sirkumfiks, interfiks, dan transfiks. Prefiks merupakan bentuk dasar yang mendapatkan imbuhan afiks didepannya. Dalam bahasa indonesia prefiks sendiri dibedakan atas dua jenis yaitu prefiks asli dan prefiks serapan. Sufiks adalah bentuk dasar yang dibelakangnya diimbuhkan afiks. Sufiks biasanya disebut akhiran atau imbuhan yang digabungkan di akhir kata. Keberadaan sufiks dapat ada beriringan dengan afiks-afiks yang lain. Dalam bahasa indonesia sufiks dibedakan menjadi dua jenis yaitu sufiks asli dan sufiks serapan. Sedangkan konfiks adalah bentuk dasar yang mendapat imbuhan afiks yang diletakkan di bagian awal dan bagian akhir. Ada dua hal yang sangat diperhatikan berkenaan dengan konfiks yang terdapat dalam bahasa Indonesia. Pertama, dalam menentukan apakah dua buah afiks (prefiks dan sufiks) termasuk konfiks atau tidak yaitu dengan cara mengetahui makna gramatikal yang dihasilkan dari proses afiksasi secara konfiks. Sedangkan yang kedua, tentang konfiks me-/-kan dan me-/-i dalam bahasa indonesi di sebut sebagai konfiks atau bukan konfiks.
\end{abstract}

Kata kunci : Aiksasi, prefiks, sufiks, konfiks

\begin{abstract}
The word changes are found in various sources, one of which is in the Java Post newspaper, apparently there are many words that have changed words such as in the Politics column in the Jawa Pos newspaper, Friday 1 November 2019 edition, there are many words that have changed the words in it. Words that experience changes in the word undergo an affixation process which is part of the morphemic process in morphology. This study analyzes the affixation process contained in the Politics column in the Jawa Pos newspaper Friday 1 November 2019 edition. There are three word change processes, namely prefixes, suffixes, and confixes, from seven affixation processes. Found 20 prefixes, 7 suffixes, and 20 confixes. Affixation is a basic form that undergoes affixation and produces new words. The affixation process is divided into seven types, namely prefix, suffix, infix, confix, circumfix, interfix, and transfix. Prefix is a basic form that gets affix affixes in front of it. In Indonesian prefixes themselves are divided into two types namely original prefixes and absorption prefixes. Suffix is the basic form behind which affix is added. Suffixes are usually called suffixes or affixes that are joined at the end of words. The existence of suffixes can coexist with other affixes. In Indonesian suffixes are divided into two types namely original suffixes and absorption suffixes. While confix is the basic form that gets affix affix which is placed at the beginning and the end. There are two things that are very concerned about confixes contained in the Indonesian language. First, in determining whether two affixes (prefixes and suffixes) are confixed or not, namely by knowing the grammatical meaning that results from the confixation affixation process. Whereas the second, concerning confix me - / - right and me - / - $i$ in Indonesian is referred to as confix or not confix.
\end{abstract}

Keywords: Fixation, prefix, suffix, confix 


\section{PENDAHULUAN}

Era globalisasi saat ini di usia anak-anak atau remaja bahkan orang tua sudah jarang mencari informasi melalui koran atau surat kabar yaitu dengan cara membaca koran. Mereka lebih suka mencari dan mendapatkan informasi melalui media sosial atau dengan menggunakan gawai. Namun, tidak sdikit juga orang-orang mencari informasi di koran atau surat kabar. Di koran jawa pos ternyata banyak kata yang mengalami perubahan kata seperti pada kolom Politik di koran Jawa Pos edisi Jumat 1 November 2019, terdapat banyak kata yang mengalami perubahan kata didalamnya. Kata-kata yang mengalami perubahan kata tersebut mengalami proses afiksasi yang merupakan bagian dari proses morfemis dalam morfologi.

Morfologi adalah kajian ilmu linguistik yang mempelajari seluk beluk struktur kata serta bagaimana pengaruh perubahannya. Morfologi dapat dikatakan sebagai satuan susunan bahasa paling kecil yang mempunyai arti. Dalam kajian morfologi terdapat proses morfemis yang didalamnya membahas proses afiksasi dan proses reduplikasi pada kata. Namun, dalam penelitian ini hanya difokuskan pada prosese afiksasi. Menurut Abdul Chaer afiksasi merupakan proses menambahkan afiks pada satu buah dasar atau bentuk dasar. Sedangkan afiks merupakan suatu bentuk, yang kebanyakan berupa morfem terikat, kemudian diimbuhkan ke dalam bentuk dasar pada saat proses pembentukan kata. Afiksasi juga dapat disebut sebagai pengimbuhan. Berdasarkan proses penambahan afiks pada bentuk dasar, afiksasi dibagi menjadi 7 jenis yaitu prefiks, sufiks, infiks, konfiks, sirkumfiks, interfiks, dan transfiks.
Pertama, prefiks merupakan imbuhan yang diletakkan di awal bentuk dasar. Prefiks biasa disebut sebagai awalan. Kedua, sufiks adalah bentuk dasar yang mendapatkan imbuhan afiks di akhir. Sufiks biasa dikenal sebagai akhiran. Tiga, infiks merupakan proses pengimbuhan pada bentuk dasar yang berada di tengah. Infiks biasa disebut sisipan atau imbuhan yang disisipkan didalam kata. Keempat, konfiks adalah proses diimbuhkannya afiks pada bentuk dasar yang diletakkan di bagian awal dan bagian akhir bentuk dasar. Kelima, sirkumulfiks merupakan afiks yang dalam prosesnya terdapat ciri-ciri segmental yang menyatu pada bentuk dasar. Simulfiks berfungsi untuk membentuk kata kerja atau verba. Simulfiks juga dapat diartikan dengan peleburan kata. Kata yang dapar disimulfikskan hanya kata yang memiliki awalan hurup k,t,s,p. Keenam, interfiks adalah proses yang didalamnya menggabungkan dua buah unsur yang, yaitu unsur penyambung dan unsur infiks. Bahasa yang menggunakan proses interfiks dalam pembentukan kata sering ditemukan pada bahasa Indo German. Ketujuh, transfiks adalah keseluruhan dasar yang mendapatkan imbuhan afiks yang berupa vokal-vokal. Proses perubahan kata secara transfiks dapat ditemukan dalam bahasa Srmpit (Ibrani dan Arab). Dalam bahasa tersebut proses transfiks dapat diimbuhkan pada konsonan-konsonan.

Dalam penelitian ini difokuskan pada proses afiksasi yang terdapat pada kolom Politik di koran Jawa Pos edisi Jumat 1 November 2019. Oleh karena itu, agar dapat lebih memahami tentang bagaimana struktur kata beserta pengaruh perubahannya pada proses morfemis secara afiksasi. Hendaknya kita dapat lebih mempelajari pokok- 
pokok pembahasan yang ada dalam materi morfologi dan analisis proses afiksasi yang dibahas pada penelitian ini.

Berdasarkan latar belakang tersebut maka dalam penelitian ini berfokus pada bagaiman proses afiksasi dalam kolom Politik di koran Jawa Pos edisi Jumat 1 November 2019. Penelitian ini bertujuannya untuk menganalisis proses afiksasi dalam kolom Politik di koran Jawa Pos edisi Jumat 1 November 2019.

Penelitian ini menggunakan metode kualitatif. Bogdan dan Taylor (Moleong, 2002:3) mendefinisikan pendekatan kualitatif sebagai prosedur penelitian yang menghasilkan data deskriptif berupa kata- kata tertulis atau lisan dari orang-orang dan perilaku yang diamati.

Indikasi dari model penelitian ini yang membedakannya dengan penelitian jenis lainnya, antara lain:

1) adanya latar alamiah;

2) manusia sebagai alat atau instrumen;

3) metode kualitatif;

4) analisis data secara induktif;

5) teori dari dasar (grounded theory);

6) deskriptif;

7) lebih mementingkan proses dari pada hasil;

8) adanya batas yang ditentukan oleh fokus;

9) adanya kriteria khusus untuk keabsahan data;

10)desain yang bersifat sementara;

11)hasil penelitian dirundingkan dan disepakati bersama.

Teknik pengumpulan data menggunakan teknik baca dan catat. Sedangkan teknik analisis data nalisis data penelitian ini akan dilakukan berdasarkan langkahlangkah berikut:
1. mereduksi data yang terdapat pada Koran Jawa Pos Edisi Jumat 1 November 2019

2. mengenali proses derivasi dan infleksi pada Koran Jawa Pos Edisi Jumat 1 November 2019

3. menganalisis data sesuai dengan teori

4. menyimpulkan hasil analisis proses derivasi dan infleksi Koran Jawa Pos Edisi Jumat 1 November 2019

\section{PEMBAHASAN}

Dalam kolom Politik di koran Jawa Pos edisi Jumat 1 November 2019 terdapat kata-kata yang mengalami proses afiksasi. Namun, ditemukan kata-kata yang mengalami proses perubahan kata secara afiksasi dalam kolom tersebut hanya tiga dari tujuh bagian pada proses afiksasi, yaitu prefiks, sufiks, dan konfiks. Didalamnya terdapat 20 prefiks yaitu kata terbukti, sejumlah, dimulai, memulai, terbatas, berbeda, berlangsung, berjalan, memakan, diubah, meminta, terkait, dibahas, diuji, memilih, setelah, meninjau, terpenting, terbuka, dan mendengar. Terdapat 7 sufiks yaitu kata hujatan rumusan, tahapan, aturan, pijakan, masukan, dan larangan. Dan terdapat 20 konfiks yaitu kata pelaksanaan, mengatakan, pembahasan, diharapkan, keamanan, memiliki, berdampingan, perkumpulan, kepentingan, melibatkan, pelaksanaan, diimplementasikan, kepresidenan, kesempatan, perbaikan, keserentakan, kesalahan, melibatkan, dilaksanakan, dan dihasilkan. Untuk lebih jelasnya perhatikan tabel di bawah ini.

\begin{tabular}{|c|c|c|c|c|c|c|}
\hline $\begin{array}{l}\mathbf{N} \\
\mathbf{o}\end{array}$ & $\begin{array}{c}\text { Pref } \\
\text { ika }\end{array}$ & Kata & $\begin{array}{l}\text { Suf } \\
\text { iks }\end{array}$ & Kata & $\begin{array}{l}\text { Kon } \\
\text { fiks } \\
\end{array}$ & Kata \\
\hline 1 & ter- & $\begin{array}{l}\text { terbuk } \\
\text { ti }\end{array}$ & -an & $\begin{array}{l}\text { hujat } \\
\text { an }\end{array}$ & $\begin{array}{l}\text { pe- } \\
\text { /-an }\end{array}$ & $\begin{array}{l}\text { pelaksana } \\
\text { an }\end{array}$ \\
\hline 2 & se- & $\begin{array}{l}\text { sejuml } \\
\text { ah }\end{array}$ & -an & $\begin{array}{l}\text { rum } \\
\text { usan }\end{array}$ & $\begin{array}{l}\text { di-/- } \\
\text { kan }\end{array}$ & $\begin{array}{l}\text { diimpleme } \\
\text { ntasikan }\end{array}$ \\
\hline 3 & di- & dimula & -an & taha & men & mengataka \\
\hline
\end{tabular}




\begin{tabular}{|c|c|c|c|c|c|c|}
\hline . & & $\mathrm{i}$ & & pan & $\begin{array}{l}\mathrm{g}- \\
/ \mathrm{ka} \\
\mathrm{n}\end{array}$ & $\mathrm{n}$ \\
\hline $\begin{array}{l}4 \\
.\end{array}$ & me- & $\begin{array}{l}\text { memul } \\
\text { ai }\end{array}$ & -an & $\begin{array}{l}\text { atur } \\
\text { an }\end{array}$ & $\begin{array}{l}\text { men } \\
\text { g- } \\
\text { /an }\end{array}$ & $\begin{array}{l}\text { mengusulk } \\
\text { an }\end{array}$ \\
\hline $\begin{array}{l}5 \\
.\end{array}$ & ter- & $\begin{array}{l}\text { terbat } \\
\text { as }\end{array}$ & -an & $\begin{array}{l}\text { pijak } \\
\text { an }\end{array}$ & $\begin{array}{l}\text { peN } \\
-/- \\
\text { an }\end{array}$ & $\begin{array}{l}\text { pembahas } \\
\text { an }\end{array}$ \\
\hline 6 & ber- & $\begin{array}{l}\text { berbe } \\
\text { da }\end{array}$ & -an & $\begin{array}{l}\text { mas } \\
\text { ukan }\end{array}$ & $\begin{array}{l}\text { di-/- } \\
\text { kan }\end{array}$ & $\begin{array}{l}\text { diharapka } \\
\mathrm{n}\end{array}$ \\
\hline 7 & ber- & $\begin{array}{l}\text { berlan } \\
\text { gsung }\end{array}$ & -an & $\begin{array}{l}\text { laran } \\
\text { gan }\end{array}$ & $\begin{array}{l}\text { ke- } \\
\text { /-an }\end{array}$ & keamanan \\
\hline 8 & ber- & $\begin{array}{l}\text { berjala } \\
\mathrm{n}\end{array}$ & & & $\begin{array}{l}\text { ke- } \\
\text { /-an }\end{array}$ & $\begin{array}{l}\text { kepreside } \\
\text { nan }\end{array}$ \\
\hline 9 & me- & $\begin{array}{l}\text { mema } \\
\text { kan }\end{array}$ & & & $\begin{array}{l}\text { me/ } \\
-\mathrm{i}\end{array}$ & memiliki \\
\hline $\begin{array}{l}1 \\
0\end{array}$ & di- & diubah & & & $\begin{array}{l}\text { ke- } \\
/ \text {-an }\end{array}$ & $\begin{array}{l}\text { kesempata } \\
\mathrm{n}\end{array}$ \\
\hline $\begin{array}{l}1 \\
1\end{array}$ & me- & $\begin{array}{l}\text { memin } \\
\text { ta }\end{array}$ & & & $\begin{array}{l}\text { pe- } \\
/ \text {-an }\end{array}$ & $\begin{array}{l}\text { pelaksana } \\
\text { an }\end{array}$ \\
\hline $\begin{array}{l}1 \\
2\end{array}$ & ter- & terkait & & & $\begin{array}{l}\text { per- } \\
\text { /-an }\end{array}$ & $\begin{array}{l}\text { perkumpu } \\
\text { lan }\end{array}$ \\
\hline $\begin{array}{l}1 \\
3\end{array}$ & di- & $\begin{array}{l}\text { dibaha } \\
\mathrm{s}\end{array}$ & & & $\begin{array}{l}\text { ke- } \\
/ \text {-an }\end{array}$ & $\begin{array}{l}\text { keserenta } \\
\text { kan }\end{array}$ \\
\hline $\begin{array}{l}1 \\
4\end{array}$ & di- & diuji & & & $\begin{array}{l}\text { ber- } \\
\text { /-an }\end{array}$ & $\begin{array}{l}\text { berdampin } \\
\text { gan }\end{array}$ \\
\hline $\begin{array}{l}1 \\
5\end{array}$ & $\begin{array}{l}\mathrm{me} \\
\mathrm{m}-\end{array}$ & $\begin{array}{l}\text { memili } \\
\mathrm{h}\end{array}$ & & & $\begin{array}{l}\text { di-/- } \\
\text { kan }\end{array}$ & $\begin{array}{l}\text { dilaksanak } \\
\text { an }\end{array}$ \\
\hline $\begin{array}{l}1 \\
6\end{array}$ & se- & $\begin{array}{l}\text { setela } \\
\mathrm{h}\end{array}$ & & & $\begin{array}{l}\text { di-/- } \\
\text { kan }\end{array}$ & dihasilkan \\
\hline $\begin{array}{l}1 \\
7\end{array}$ & $\begin{array}{l}\text { me } \\
N-\end{array}$ & $\begin{array}{l}\text { meninj } \\
\mathrm{au}\end{array}$ & & & $\begin{array}{l}\text { ke- } \\
/ \text {-an }\end{array}$ & $\begin{array}{l}\text { kepenting } \\
\text { an }\end{array}$ \\
\hline $\begin{array}{l}1 \\
8\end{array}$ & ter- & $\begin{array}{l}\text { terpen } \\
\text { ting }\end{array}$ & & & $\begin{array}{l}\text { me- } \\
/- \\
\text { kan }\end{array}$ & $\begin{array}{l}\text { melibatka } \\
\mathrm{n}\end{array}$ \\
\hline $\begin{array}{l}1 \\
9\end{array}$ & ter- & $\begin{array}{l}\text { terbuk } \\
\text { a }\end{array}$ & & & $\begin{array}{l}\text { ke- } \\
/ \text {-an }\end{array}$ & kesalahan \\
\hline $\begin{array}{l}2 \\
0\end{array}$ & $\begin{array}{l}\mathrm{me} \\
\mathrm{N}-\end{array}$ & $\begin{array}{l}\text { mende } \\
\text { ngar }\end{array}$ & & & $\begin{array}{l}\text { per- } \\
\text { /-an }\end{array}$ & perbaikan \\
\hline
\end{tabular}

\section{Afiksasi}

Afiksasi adalah proses diimbuhkannya afiks pada bentuk dasar. Menurut Abdul Chaer Afiksasi merupakan proses menambahkan afiks pada satu bentuk dasar. Sedangkan menurut Ramlan afiks ialah satuan unsur gramatikal terkecil yang didalamnya suatu kata merupakan unsur yang bukan kata dan bukan pokok kata, yang memiliki kesanggupan melekat pada satuan lain untuk membentuk kata lain untuk membentuk kata baru. Proses afiksasi didalamnya mencakup beberapa unsur-unsur yaitu bentuk dasar, imbuhan (afiks), dan makna gramatikal. Proses afiksasi dapat bersifat derivatif dan bersifar inflektif. Tetapi tidak semua bahasa ada proses afiksasi.

Afiks merupakan suatu bentuk, yang kebanyakan berupa morfem terikat, kemudian diimbuhkan ke dalam bentuk dasar pada saat proses pembentukan kata. Pengimbuhan merupakan kata lain dari proses afiksasi. Bentuk dasar yang mengalami proses afiksasi yaitu bentuk dasar yang tidak bisa disekmentasikan kembali dan merupakan bentuk terkecil. Berdasarkan proses penambahan afiks pada bentuk dasar, proses afiksasi dibagi menjadi tujuh jenis yaitu prefiks, sufiks, infiks, konfiks, sirkumfiks, interfiks, dan transfiks. Dari pendapt-pendapat tersebut dapat disimpulkan bahwa afiksasi adalah proses pengimbuhan afiks pada bentuk dasar yang menghasilkan kata baru.

Proses afiksasi yang dapat membentuk kata kerja yaitu prefiks, infiks, sufiks, dan konfiks. Bentuk prefiks yang dapat menjadiakn kata kerja terdiri dari [ke-], [meN-], [di-], [ber-], [se-], [per], [ter-], [peN-], [maha-], [pra-], [tuna-], [a-], [non-], [inter-], [dwi-], [swa-], [anu], [anti-], [mikro-], [auto-], [epi-], [hetero], [super-], dan [homo-]. Infiks yang menjadikan kata kerja yaitu [-el-], [-er-], dan [-em-]. Sufiks yang menjadikan kata kerja yaitu [-an], [-i], [-nya], [-kan], [man], [-wan], [-wati], [-is], [-isasi], [isme], [-in], [-i], [-at], dan [-a]. Dan konfiks yang menjahikan kata kerja yaitu [ber-/-an], [ber-/-kan], [ke-/-an], [pe-/an], [per-/-an], [se-/-nya], [me-/-an], dan [di-/-kan]. 
1. Prefiks

Prefiks merupakan imbuhan yang diletakkan di awal bentuk dasar. Prefiks dapat juga disebut awalan atau imbuhan yang ada di depan kata. Menurut Abdul Chaer, prefiks ialah bentuk dasar yang mendapatkan imbuhan afiks di depannya. Menurut Verhaar prefiks adalah afiks yang diimbuhkan di bagian kiri bentuk dasar. Proses afiksasi secara prefiks ada yang tidak mengakibatkan perubahan kelas kata dan juga ada yang mengakibatkan perubahan kelas kata. Dalam bahasa indonesia prefiks dibedakan menjadi dua jenis, antara lain :

a. Prefiks asli yaitu prefiks yang berasal dari bahasa indonesia. Pefiks asli meliputi [ke-], [me-], [di-], [ber-], [se-], [per-], [ter-], [peN-].

b. Prefiks serapan yaitu prefiks yang berasal dari bahasa asing atau dari bahasa daerah. Prefiks serapan terdiri atas prefiks [maha-], [pra-], [tuna-], [a-], [non], [inter-], [dwi-], [swa-], [anu-], [anti-], [mikro-], [auto-], [epi-], [hetero-], [super-], [homo-].

Dalam analisis prefiks ini akan terfokus pada prefiks asli. Prefiks [ke-], prefiks [ke-] jika diimbuhkan pada bentuk dasar akan membentuk verba pasif intransitif dan dapat diimbuhkan pada bentuk dasar yang berupa adjektif atau kata benda, verba atau kata kerja, nomina, dan prakategorial.

Prefiks [me-], prefiks [me-] jika diimbuhkan pada bentuk dasar akan berada menjadi verba aktif dan dapat diimbuhkan pada bentuk dasar yang termasuk dalam kelas kata verba atau kata kerja, nomina, dan prakategorial. Proses diimbuhkannya prefiks [me] pada bentuk dasar, hendaknya diperhatikan tiga hal berikur. Pertama, penetapan fonem yaitu dalam proses mengimbuhkan prefiks [me-] pada bentuk dasar tidak terjadi pelepasan dan penambahan fonem. Bentuk dasar yang berawalan konsonan [l, m, n, r, w, y, ny, dan ng]. Kedua, penambahan fonem yaitu dalam proses pengimbuhan prefiks [me-] pada bentuk dasar terjadi penambahan fonem [n, $m, n g$, dan nge]. Bentuk dasar yang berawalan konsonan [d] akan mendapat tambahan fonem [n], bentuk dasar yang berawalan konsonan [b] dan [f] akan mendapat tambahan fonem [m], bentuk dasar yang berawalan konsonan [h, kh, g, e, u, a, i, dan o] akan mendapat tambahan fonem [ng], dan bentuk dasar yang hanya satu kata akan mendapat tambahan fonem [nge]. Ketiga, meluluhnya fonem dalam proses pengimbuhan prefiks [ber-] pada bentuk dasar yang huruf awalnya berupa konsonan [s,p,t, dan k]. Bentuk dasar yang huruf awaknya [s] akan meluluh menjadi [ny], bentuk dasar yang huruf awaknya [p] akan meluluh menjadi [m], bentuk dasar yang huruf awaknya [t] akan meluluh menjadi [n], dan bentuk dasar yang huruf awaknya [k] akan meluluh menjadi [ng].

Sedangkan prefiks [di-], prefik [di-] dapat dilimbuhkan pada bentuk dasar yang berupa kata benda, kata kerja, nomina, dan prakategorial. Kata yang mendapat imbuhan prefiks [di-] akan berada verba pasif. Prefiks [ber-], dalam mengimbuhkan prefiks [ber-] pada bentuk dasar terdapat tiga hal yang harus diperhatiakan karena akan menghasilkan perubahan fonem. Pertama, dilepaskanya fonem [r] pada prefiks [ber-] ketika diimbuhkan ke bentuk 
dasar yang berawalan huruf r,k,t,c. Kedua, huruf [r] pada prefik [ber-] akan berubah menjadi huruf [i] ketika diimbuhkan pada bentuk dasar [ajar]. Ketiga, pada prefiks [ber-] huruf [r] akan tetap jika bentuk dasar tidak terdapat di penjelasan pertama dan kedua. Prefiks [per-], prefiks [per-] kerika diimbuhkan pada bentuk dasar hendaknya memperhatiak tiga hal berikut. Pertama, melepasnya fonem [r] pada bentuk dasar yang berawalan huruf [r] atau bentuk dasar dengan suku kata pertama [er]. Kedua, fonem [r] berubah menjadi fonem [i] pada bentuk dasar [ajar]. Ketiga, fonem [r] akan tetap jika diimbuhkan pada bentuk dasar selain yang dijelaskan pada poin pertama dan kedua. Prefiks [ter-], prefiks [per-] kerika diimbuhkan pada bentuk dasar terlebih dahulu memperhatiak tiga hal berikut. Pertama, fonem [r] akan dilepaskan jika bentuk dasar yang huruf awalnya [r] mendapat imbuhan prefiks [ter-]. Kedua, jika prefiks [ter] diimbuhkan ke bentuk dasar [anjur] akan mengakibatkan berubahnya fonem [r] menjadi [i]. Ketiga, tidak berubahnya fonem [r] jika bentuk dasar mendapat imbuhan prefiks [ter-] tidak mengalami perubahan seperti yang dijelaskan pada poin pertama dan kedua.

Contoh:

1) Prefiks [ter-] pada kata terbukti terbukti $=$ [ter-], dan [bukti]

Kata terbukti berasal dari bentuk dasar bukti yang mendapat imbuhan berupa prefiks ter- di depannya. Dalam hal ini mengakibatkan perubahan kelas kata. Karena kata terbukti terdapat pada kelas kata yang berupa kata kerja dan bukti termasuk dalam kelas kata nomina.

2) Prefiks [ber-] pada kata berlangsung

berlangsung $=$ [ber- $]$ dan [langsung]

Kata berlangsung berasal dari bentuk dasar langsung yang mendapat imbuhan berupa prefiks ber- di depannya. Dalam hal ini tidak mengakibatkan perubahan kelas kata. Karena kata berlangsung terdapat pada kelas kata yang berupa kata kerja dan langsung juga termasuk kelas kata yang berupa kata kerja.

3) Prefika [meN-] pada kata mendengar

mendengar $=$ meN-, dan dengar

Kata mendengar berasal dari bentuk dasar dengar yang mendapat imbuhan berupa prefiks meN- di depannya. Dalam hal ini tidak mengakibatkan perubahan kelas kata. Karena kata mendengar terdapat pada kelas kata yang berupa kata kerja dan dengar juga merupakan kata kerja.

2. Sufiks

Sufiks adalah bentuk dasar yang mendapatkan imbuhan afiks di akhir. Sufiks dapat juga disebut akhiran atau imbuhan yang dirangkaikan di akhir kata. menurut Abdul Chaer, sufiks merupakan afiks yang diimbuhkan pada posisi akhir bentuk dasar. Proses ini dapat membantuk kata baru. Keberadaan sufiks dapat ada beriringan dengan afiks-afiks yang lain. Dalam bahasa indonesia sufiks dibedakan menjadi dua jenis, yaitu:

a. Sufiks asli yaitu sufiks yang berasal dari bahasa indonesia. Sufiks asli meliputi akhiran[ -an], [-i], [-nya], dan [-kan]. 
b. Sufiks serapan yaitu prefiks yang berasal dari bahasa asing atau dari bahasa daerah. Sufiks serapan meliputi akhiran [-man], [-wan], [-wati], [-is], [-isasi], [isme], [-in], [-i], [-at], [-a].

Sufiks [-i], sufiks [-i] -] jika diimbuhkan pada bentuk dasar akan membentuk verba aktif transitif dan dapat dilimbuhkan pada bentuk dasar yang berupa adjektif atau kata benda, verba atau kata kerja, nomina, dan prakategorial. Sufiks [-an], sufiks [-an] jika diimbuhkan pada bentuk dasar akan membentuk verba aktif intransitif.

Contoh:

1) Sufiks [-an] pada kata tahapan tahapan $=$ [tahap], dan [-an] Kata tahapan terbentuk dari bentuk dasar tahap yang mendapat imbuhan berupa sufiks -an di belakangnya. Dalam proses ini tidak mengakibatkan perubahan kelas kata. Karena kata tahapan terdapat pada kelas kata nomina dan tahap juga termasuk dalam kelas kata nomina.

2) Sufiks [-kan] pada kata pijakan pijakan $=$ [pijak], dan [-an]

Kata pijakan berasal dari bentuk dasar pijak yang mendapat imbuhan berupa sufiks -an di belakangnya. Pada proses ini tidak mengakibatkan perubahan kelas kata. Karena kata pijakan terdapat pada kelas kata nomina dan pijak juga termasuk dalam kelas kata nomina.

3) Sufiks [-an] pada kata aturan aturan $=$ [atur $]$, dan [-an]

Kata aturan berasal dari bentuk dasar atur yang mendapat imbuhan berupa sufiks -an di belakangnya. Dalam proses ini terjadi perubahan kelas kata.
Karena kata aturan termasuk dalam kelas kata nomina dan atur termasuk dalam kelas kata yang berupa kata kerja atau verba.

3. Konfiks

Konfiks adalah proses menambahkan imbuhan pada bentuk dasar yang diletakkan di bagian awal dan bagian akhir bentuk dasar. Konfiks merupakan gabungan dari prefiks dan sufiks yang terletak di awal dan akhir kata. Menurut Abdul Chaer, konfiks adalah afiks yang termasuk dalam morfem terbagi, yang bagian pertama berada diawal bentuk dasar, dan yang bagian kedua berada diakhir bentuk dasar. Kedua bagian afiks dianggap sebagai satu kesatuan, pengimbuhannya dilakukan sekaligus, tidak ada yang lebih dahulu, dan tidak ada yang lebih kemudian. Konfiks terdapat di satu makna gramatikal pada satu kata.

Terdapat dua hal yang harus diperhatikan berkaitan dengan konfiks di dalam bahasa Indonesia. Pertama, dalam menentukan apakah dua buah afiks (prefiks dan sufiks) termasuk konfiks atau tidak yaitu dengan cara mengetahui makna gramatikal yang dihasilkan dari proses afiksasi secara konfiks. Seperti ber-/-an dapat dikatakan konfiks dan dapat dikatakan bukan konfiks kerika diibuhkan pada bentuk dasar. Bentuk ber-/-an dapat dikatakan sebagai konfiks jika keduanya diimbuhkan pada bentuk dasar secara bersamaan. Kedua, tentang konfiks dalam bahasa indonesi yang berkenaan dengan bentuk me-/-kan dan me-/-i. Ada berbagai alasan yang berbeda pada bentuk me-/-kan dan me-/-i di sebut sebagai konfiks atau bukan konfiks. Bentuk tersebut bukan dikatakan konfiks karena bentuk sufiks -kan 
dan -i merupakan afiks pembantuk kata atau afiks derivatif. Dalam menentukan bahwa bukan konfiks secara linier dapat juga menggunakan teknik Immediate Constituents. Bentuk me-/-kan dan $m e-/-i$ dapat dikatakan konfiks karena me-/-kan dan me-/-i dapat diubah menjadi di-/-kan dan di-/-i, dari bentuk aktif indikatif menjadi bentuk pasif indikatif. Untuk lebih jelasnya perhatikan pada gambar 1.1. Konfiks (awalan dan akhiran) antara lain: per-an, ke-an, se-nya, ber-an, me-kan dan peN-an.

\section{Gamabr 1.1}

\section{me lewat}

Dari gambar 1.1 kata melewati termasuk bentuk konfiks karena pada akhir kata dasar lewat mendapat akhiran -i terlebih dahulu, termasuk bentuk dari afiks derivatif yang menghasilkan kata lewati. Kemudian baru mendapatkan imbuhan prefiks me- didepannya, sehingga membentuk kata melewati. Bentuk konfiks yaitu [ber-/-an], [ber/-kan], [ke-/-an], [pe-/-an], [per-/an], [se-/-nya], [me-/-kan], dan [di-/kan].

Contoh kata yang merupakan bentuk konfiks, antara lain:

a. Konfiks ke-/-an pada kata kesempatan

kesempatan $=[\mathrm{ke}-/-\mathrm{an}]$ dan [sempat]

Kata kesempatan berasal dari bentuk dasar sempat yang mendapat imbuhan berupa konfiks ke-/-an. Dalam proses ini terjadi perubahan kelas kata. Karena kata kesempatan termasuk dalam kelas kata nomina dan sempat termasuk dalam kelas kata yang berupa kata kerja atau verba. b. Konfiks per-/-an pada kata perbaikan

perbaikan $=[$ per $-/$-an] dan [baik]

Kata perbaikan berasal dari bentuk dasar baik yang mendapat imbuhan berupa konfiks ber-/-an. Dalam proses ini terjadi perubahan kelas kata. Karena kata perbaikan termasuk dalam kelas kata nomina dan baik termasuk dalam kelas kata yang berupa kata kerja atau adjektiva.

c. Konfiks me-/-i pada kata memiliki

memiliki $=[\mathrm{me}-/-\mathrm{i}]$ dan $[$ milik $]$

Kata memiliki berasal dari bentuk dasar milik yang mendapat imbuhan berupa konfiks me-/-i. Dalam proses ini terjadi perubahan kelas kata. Karena kata memiliki termasuk dalam kelas kata yaitu kata kerja dan milik termasuk dalam kelas kata yang berupa nomina.

\section{Simpulan}

Pada penelitian ini dapat disimpulkan tentang menganalisis proses afiksasi yang terdapat pada kolom Politik di koran Jawa Pos edisi Jumat 1 November 2019. Didapatkan tiga proses perubahan kata yaitu prefiks, sufiks, dan konfiks, dari tujuh proses afiksasi. Ditemukan 20 prefiks, 7 sufiks, dan 20 konfiks. Afiksasi merupakan bentuk dasar yang mengalami proses pingimbuhan afiks dan menghasilkan kata baru. Proses afiksasi dibagi menjadi tujuh jenis yaitu prefiks, sufiks, infiks, konfiks, sirkumfiks, interfiks, dan transfiks.

Prefiks adalah bentuk dasar yang mendapatkan imbuhan afiks didepannya. Prefiks dapat juga disebut sebagai awalan. Dalam bahasa indonesia prefiks sendiri dibedakan atas dua jenis yaitu prefiks asli dan prefiks serapan. Pefiks asli meliputi awalan [ke-], [me-], [di-], 
[ber-], [se-], [per-], [ter-], [peN-]. Sedangkan prefiks serapan terdiri atas prefiks [maha-], [pra-], [tuna-], [a-], [non], [inter-], [dwi-], [swa-], [anu-], [anti-], [mikro-], [auto-], [epi-], [hetero-], [super], [homo-].

Sufiks adalah bentuk dasar yang dibelakangnya diimbuhkan afiks. Sufiks biasanya disebut akhiran atau imbuhan yang digabungkan di akhir kata. Keberadaan sufiks dapat ada beriringan dengan afiks-afiks yang lain. Dalam bahasa indonesia sufiks dibedakan menjadi dua jenis yaitu sufiks asli dan sufiks serapan. Sufiks asli meliputi akhiran [-an], [-i], [-nya], dan [-kan]. Sedangkan sufiks serapan meliputi akhiran [-man], [-wan], [-wati], [-is], [isasi], [- isme], [-in], [-i], [-at], [-a].

Sedangkan konfiks adalah bentuk dasar yang mendapat imbuhan afiks yang diletakkan di bagian awal dan bagian akhir. Konfiks merupakan gabungan dari prefiks dan sufiks yang terletak di awal dan akhir kata. Ada dua hal yang sangat diperhatikan berhubungan dengan konfiks yang terdapat dalam bahasa Indonesia. Pertama, dalam menentukan apakah dua buah afiks (prefiks dan sufiks) termasuk konfiks atau tidak yaitu dengan cara mengetahui makna gramatikal yang dihasilkan dari proses afiksasi secara konfiks. Sedangkan yang kedua, tentang konfiks dalam bahasa indonesi yang merupakan bentuk me-/-kan dan me-/-i. Ada beberapa alasan yang berbeda pada bentuk me-/-kan dan me-/-i di sebut sebagai konfiks atau bukan konfiks.

\section{DAFTAR PUSTAKA}

Chaer, Abdul. 2014. Linguistik Umum. Jakarta: Rineka Cipta

Chaer, Abdul. 2008. Morfologi Bahasa Indonesia (Pendekatan Proses). Jakarta: Rineka Cipta

Jawa Pos. 2019. "Janji Revisi UU Pemilu Lebih Awal". Surabaya. 1 November

Lexy J. Moleong. 2002. Metodologi Penelitian Kualitatif. Bandung: PT. Remaja Rosdakarya.

www.laelitm. 2019. "Pengertian Afiksasi, Jenis Afiks, Contoh, dan Keterangannya". 1 Desember 2019 